\title{
Urban Refugees: Introduction
}

\author{
Anita Fábos and Gaim Kibreab
}

\section{Introduction}

$\mathrm{I}$ nterest in refugees who live in urban settings, especially those of the global south, has developed fairly recently, although refugees themselves have always been part of urban society. In 2002, the Forced Migration and Refugee Studies program at the American University in Cairo held a workshop to explore some of the methodological and ethical issues implicit in doing research among urban refugee populations in developing societies. Many of the papers in this issue developed from this initial endeavour. However, it was evident that the contributing authors had concerns with the systemic context for urban refugees that went beyond the epistemological aspects of the research process. In particular, the experiences of refugees in the cities described by contributors-Kampala, Cairo, Johannesburg, Khartoum-are characterized by a high level of vulnerability stemming from arbitrary and schizophrenic international protection policies deriving from anxieties embodied by the nation-state system.

This special issue is devoted to the analyses of political, social, economic, and legal barriers for refugees in urban settings, particularly as these shape the opportunities, strategies, vulnerabilities, and livelihoods of refugees in African cities. We are interested in framing the central thrusts of the contributions through considering regional urbanization, shifts in global patterns of refugee movements, and transnationalism. State policies concerning immigration, naturalization, and citizenship produce some of the structural factors shaping these complex developments, although to a large degree they are the inevitable result of globalization processes. The scholars whose work is represented here provide research-based evidence that policies designed to manage the symptoms of refugees "out of place" are unable to accommodate the fundamental challenge refugees pose to the nation-state system.

Clearly, state policies that tighten up borders, reduce immigration, and limit access to citizenship are at odds with regional processes of urbanization, increased population movements globally, and the development of transnational spaces, and urban refugees are caught in the middle. These policies that attempt to make the presence of refugees in urban-and national—settings illegitimate are counterproductive inasmuch as they try to counteract irresistible demographic trends.

In what follows we show that urbanization is an irreversible process in the African context, and that the movement of refugees to urban areas can only make sense in this context. Furthermore, state policies of segregation, securitization, and criminalization of urban refugees are inextricably linked to the objectives of states to create and perpetuate differences between insiders and outsiders_of which citizenship is a key determinant. Generally, refugee law is the exception to domestic immigration law because it allows certain people to enter the territories of other states without a visa or other requirements. In Africa, however, refugee law is used as an instrument of exclusion and separation- but only to hold up exclusive nationality law (Kagan in this issue). As Kibreab points out in this issue, in nearly all developing countries, refugees are received as temporary guests until the conditions that prompted their displacement are eliminated. Once the political conditions that caused displacement cease, refugees are expected to return home regardless of the duration of exile. Spatial segregation of refugees is seen as an important instrument of preventing refugees' integration into host societies by prolonging their refugee status. This strategy is defeated if refugees are settled in urban area, and helps explain why host countries in the South regulate the presence of refugees in urban areas.

Finally, the authors in this issue describe the ways in which refugees carve out a space under adverse conditions not simply by reacting to unfavourable state policies and practices but also through creative engagement and mobilization of social networks in search of viable livelihoods, often with a transnational dimension, against all odds. 
The urban spaces where the human consequences of these ongoing developments are most starkly apparent are the cities of the global South. The authors of these papers have chosen to emphasize the African context for the dramatic contrast between global and regional developments that support increased migration and population control policies that stem from the rationale of the nation-state. The rapid expansion of Cairo, for example, from a city of half a million people in the 1940s to the eighteen million plus of today is largely due to rural-urban migration. The Egyptian state has sought to control and counteract this process through denying permission for house-building, slum-clearing, relocation of wholesale markets where rural migrants make a living to the desert beyond city limits, and other mechanisms of urban planning. The population of Khartoum, on the other hand, has swelled due to famine and war in other parts of the country; the Sudanese government has reacted by criminalizing begging, bulldozing settlements of displaced Sudanese and moving their people to more distant sites, among other things. In both cases, moving to the capital city represents access to security, services, and opportunities for citizens whose governments seek to keep them in the provinces without any regard to their physical safety and well-being.

Refugees who join the steady advance of people moving to African and other Southern cities go for particular reasons related to their search for safety, access to international links (to receive remittances, for example), and options for resettlement. However, the explorations of refugee experiences and livelihoods offered by contributors to this issue additionally illustrate that refugees choose urban areas for the same reasons as citizens do. Even in the most poor countries in Africa, the relationship between urban and rural areas is marked by uneven development and skewed distribution of opportunities for income-generation, education, health care, housing, clean water supply, and sanitation, as well as transportation. Evidence abounds that the level of income earned by urban dwellers, including those who live in slum areas, is higher than in rural areas. As might be expected, refugees-like other people-are strategic decision makers and may "vote with their feet" en route for cities where chances of staying on the right side of the razor's edge of survival are better.

Another attraction of the city is the opportunity for anonymity. In comparison to national urban dwellers, the number of refugees in African cities is insignificant and, as a result, they may be able to melt into the urban throng by assuming fictive identities, ${ }^{1}$ especially if they share common language, ethnicity, and way of life. The benefit of anonymity, besides providing physical security, enables refugees to engage in different forms of income-generating activities by hiding their true identity. In Sudan, for example, according to the Sudanese Asylum Act 1974 refugees are prohibited from leaving the officially designated places of residence. They are also not allowed to own property or to leave government-designated sites without permission. There are tens of thousands of Eritrean refugees, especially those who share common traits of ethnicity, religion, language, and way of life with some members of the local community in Eastern Sudan who own property, who live in the cities, move freely and engage in diverse income-generating activities in defiance of the formal government policies. Most of this would have been unachievable in a rural setting, where people generally know each other and associate with one another on the basis of common residence or descent.

This does not, however, suggest that all African refugees can escape the tyranny of being "othered" by simply relocating themselves to cities. Whilst in some African contexts, such as Kassala, Kigoma, and even Dar es Salaam, ${ }^{2}$ refugees are able to hide among urban populations, passing for nationals, in others they make up a visible minority. Sudanese, Eritrean, and Congolese refugees in Cairo are routinely singled out for harassment by security forces as well as ordinary Egyptians. In either case, however, refugees are unambiguously distinguished from citizens by their legal status, rendering them ineligible for services and dependent on the beneficence of the state for residency rights. As non-citizens, they are not perceived as part of the national interest - they are seen as foreign objects in the body politic - and most policies are designed to control, contain, and segregate them from the rest of the population. The acquiescence of their fellow urbanites to these policies is achieved through state discourses and practices presenting refugees as a threat in terms of state and societal security, competition for limited resources, and the personal safety of citizens. We turn now to a discussion of state practices of spatial segregation, securitization, and criminalization of refugees in Africa with reference to international legal mechanisms designed to inhibit refugees moving to cities.

\section{The Tyranny of Spatial Segregation}

The presence of refugees in urban areas is invariably opposed by governments in nearly all African receiving countries, with few exceptions. ${ }^{3}$ On the rest of the continent, governments place refugees in spatially segregated sites wherever possible. From the narrow perspective of state interest, there are ostensibly well-thought-out policy objectives underlying the decisions of governments concerning spatial segregation of refugees. Kibreab and to some extent Kagan (both in this issue) identity a number of factors underpinning such policies-namely, minimization of per- 
ceived risks to national security, prevention of refugee competition for employment, self-employment, social services (healthcare, education, sanitation), housing, and transportation; shifting of responsibilities for catering to the needs of refugees to the refugee assistance system; creation of opportunities to develop previously neglected sites for lack of resources; and prevention or minimization of societal insecurity - e.g. the alleged cultural, racial, and religious homogeneity of national populations (Kibreab in this issue). In contrast to Northern state immigration policies, these measures actively prevent refugee integration into receiving societies. $^{4}$

Notwithstanding the fact that these policies are formulated and implemented in order to provide "solutions" to the refugee problem in first countries of asylum, in reality, they represent an obstacle to a solution by perpetuating refugee status indefinitely. Worse still, spatial segregation prevents refugees from contributing to the social and economic progress of their receiving societies. If the presence of refugees within the urban settings were to be regularized, both refugees and their hosts could derive mutual benefits stemming from the social, economic, cultural, and political interactions that take place within an urban environment.

Displacement in the context of urban settings tends to telescope processes of social change through which refugees, under pressure, acquire new skills and occupations, enter into new social relationships, and engage in economic activities that they would have never contemplated. ${ }^{5}$ Governments, by failing to realize the potential benefits of regularizing the presence of refugees in the urban areas, are forgoing resources that could partially address the malaise and economic decay that permeate African cities. The following example may shed some light on this. Successive Sudanese governments restricted the possibility for Eritrean refugees outside refugee camps and settlements to obtain business licences. In the 1980s, one of the major bottlenecks faced by the country's economy was transportation. In the mid-1980s, the government allowed Eritrean refugees to obtain licences in order to engage in the trucking business. Within a short period, there were fleets of trucks and trailers belonging to many Eritrean refugees who had returned from the Gulf States, Europe, and North America to invest their savings. Not only did this enable the refugees concerned to earn incomes, but they also enabled the host country to benefit from capital investment earned outside of the country. However, this liberal policy did not last long. One of the main reasons why subsequent government policies restricted the rights of refugees to engage in commercial activities within the urban setting is due to the strongly embedded but nevertheless unsubstantiated fear of threat to national security that might be posed by the refugees. In what follows we argue that one of the main arguments African states use try to keep their cities clear of refugees is to place the refugee question on the security agenda.

\section{Securitization of the Presence of Refugees in Urban Areas}

There is an unmistakable tendency among governments in developing countries, especially Africa, to characterize urban refuges as constituting an imminent threat to national and societal security. When an issue is securitized, argue Buzan et al., "it is presented as an existential threat, requiring emergency measures and justifying actions outside the normal bounds of political procedure." 6 The securitization of the presence of refugees in urban areas enables governments to treat refugees in urban settings contrary to the principles underlying the international instruments to which they are parties, as well as national legislation relating to refugee status and other domestic laws pertaining to human and individual rights. This is because on the one hand, security is represented as being a universal good that all members of society should strive to achieve ${ }^{7}$ and on the other, draconian measures used against refugees are justified by the alleged need to avoid dangerous scenarios of insecurity from unfolding. Not only does securitization threaten the well-being of refugees due to arbitrary state action, but it also creates a hostile environment for them by fostering paranoia and xenophobia among nationals in urban areas.

Although the securitization of the presence of refugees in urban areas is not a new phenomenon, it has intensified as a result of a number of changes that have been occurring on the continent. As outlined above, deteriorating living conditions in most rural areas have been forcing Africans to emigrate to cities in search of income-generating opportunities. These mass immigrations to urban areas have been taking place in the absence of structural transformations of urban economies (Kibreab this issue). As a result, a large majority of rural immigrants end up in urban slums, placing enormous pressure on fragile or non-existent social and physical infrastructures. The presence of refugees in urban areas that are already under enormous pressure is seen by governments and nationals as presenting a threat to economic, social, and political security. Given the enormity of economic, social, and infrastructural problems facing African cities, and given the negligible number of urban refugees, any sensible and informed debate would conclude by recognizing that the problems facing African cities have little or nothing to do with the presence of refugees.

When Africa was gripped by the "democratization process" following the end of the Cold War, many expected that the factors that produced forced migrations would come to an end-and that the victimization of refugees in urban 
areas would also cease-due to commitment of governments and citizens to the sanctity of the rule of law and human rights. This did not happen, as the example of Sudan makes very clear. Multi-party elections and freedom of the press and of expression that accompanied democratization have had unexpected but nevertheless detrimental consequences for the well-being of urban refugees. Parliamentarian candidates blamed the acute shortages in employment, housing, transportation, hospital beds, medicines, school places, and strategic commodities such as sugar, oil, etc. on refugees. Journalists and some vocal citizens unleashed an assault against urban refugees-and social scientists on the front lines ${ }^{8}$ _during the infamous 1987 kesha campaign unleashed by the democratically elected al-Mahdi government against refugees. ${ }^{9}$ Refugees were subjected to roundups, arbitrary detention, extortion, imposition of heavy penalties, etc. for allegedly imposing an "unbearable burden" on the social, economic, and physical infrastructures of the capital city and for "polluting" the "purity" of the Islamic way of life of Sudanese society. ${ }^{10}$ It is not only in Sudan that the surge of democracy brought about systematic anti-refugee attitudes; this was equally true in Tanzania and elsewhere in sub-Saharan Africa. ${ }^{11}$

It is often assumed that refugees face racism and discrimination only in the North. This belief rests upon the assumption, often reflected in international refugee policies for managing refugee flows in the South, that refugees and their hosts in Africa, Latin America, and Asia share common ethnic and socio-cultural characteristics and that refugees are therefore unlikely to face racial discrimination or prejudice. Nothing could be further from the truth. When a particular group, e.g. refugees, is labelled as "pollutants" and a "burden," its members are singled out for harassment and prejudicial treatment in the same way as are members of a particular ethnic or racial category. While the racialization of immigrants and refugees - and thus the rationale for exclusion-has been a recognized development in Europe, ${ }^{12}$ there is ample evidence to show that refugees in the South face discrimination and unfair treatment by virtue of being "outsiders" or non-citizens. ${ }^{13}$ As we suggest in the following section, one mechanism for pursuing exclusionary policies at the state level is to link refugee populations with criminality.

\section{Criminalization of Refugees in Urban Areas}

Throughout Africa, refugee policies and assistance programs are almost exclusively focused on providing protection and assistance to refugees residing in rural camps and settlements. ${ }^{14}$ To access these resources refugees are required to settle in government-designated places. These places are more often than not located in remote rural areas.
When designating a particular site for a refugee camp or settlement, host governments rarely take the needs of particular refugees into account. Those refugees who have previously never lived in rural areas, many of them urban professionals, may well consider settlement in such unfamiliar places unacceptable; such refugees spare no effort to subvert the policies and practices of host governments that are formulated and implemented without any regard to their skills and needs.

Many governments allege that refugees in urban areas are inclined to engage more often in "corrupt practices" than their counterparts in rural areas, and are thus criminalized. However, for those refugees who seek to escape from rural refugee camps and settlements, no legal avenues exist to relocate in urban areas. The only way to avoid being confined to these, in their view, inhospitable places is either through illegal departures or through payment of bribes to obtain travel permits. Once they relocate themselves to urban centres, refugees are forced to resort to "illegal" means of obtaining residence permits by bribing government officials directly or through middlemen. Many refugees in urban areas also pay exorbitant fees to obtain forged residence permits.

As is clear from the empirical research presented in this special issue - and recognized by the UNHCR - one of the reasons refugees prefer urban areas to rural camps and settlements is to try to realise their aspiration of being resettled in one of the prosperous countries of the North. Since most avenues for legal immigration or resettlement ${ }^{15}$ are closed, refugees - as well as nationals in search of a better life-resort to a myriad of illegal means of obtaining forged visas, passports, and travel and other documents. Not only are most of these illegal activities undertaken in collusion with host countries' officials and security forces, more importantly, it is the lack of consideration of the needs of refugees and the inappropriateness of host government policies and practices that compel refugees to disregard and disrespect such policies in the first place. Florencia Belvedere (in this issue) hits the nail on the head when she states:

Despite the Department's engagement in a protracted status determination process that enables both the presence of "abusers" in the asylum system and often drives desperate asylum seekers and refugees to engage in corrupt practices to secure access or documentation in the face of perpetual delays, it has become more politically expedient for the Department to portray asylum seekers as fraudsters and abusers of the system who are responsible for the failure of the asylum procedure than to admit that its own practices are working to undermine the asylum procedure... 
In the following we examine the reasons that underlie African refugees' decisions to move to cities in spite of the restrictions, harassment, extortion, and threats of arbitrary detention and deportation they face at the hands of host governments' officials.

\section{The Appeal of Cities for Refugees}

Marfleet (in this issue) $)^{16}$ points out that refugees have been part of the urban landscape throughout history for a variety of reasons. Some of these reasons have undoubtedly to do with generic processes of urbanization and the concentration of resources in one place. The contributions here also suggest a number of motives that refugees have for choosing - often in the face of bureaucratic, legal, and political obstacles-to move to cities (Lammers in this issue). As mentioned earlier, urban space provides anonymity and therefore greater personal security for refugees, a point made effectively by Sommers in his ethnography of fearful young refugees in Dar al-Salaam. The encampment policies of states and international agencies mean that refugees originating from a given country are placed in the same site. Some of these groups may be former enemies and can easily target each other. The urban space, by providing an opportunity for anonymity, provides some degree of physical security.

There is evidence to show that camps are insecure places in other ways. They can be targeted by countries of origin or by opposition groups or liberation armies, e.g. the refugee camps in northern Uganda. Sudan People's Liberation Army (SPLA) cadres also targeted southern Sudanese former combatants who escaped from the frontlines and settled in refugee camps. Before the demise of apartheid, the African National Congress (ANC) and the other liberation fronts in southern Africa had free access to the refugee camps in the neighbouring countries. They routinely victimized dissidents and alleged enemy informants. Those who feared retribution, invariably voted with their feet towards cities where they could lead anonymous lives. When host countries are allies of liberation movements, e.g. Uganda and SPLA, the former may indirectly or directly facilitate the latter's access to refugee camps for recruitment or other purposes. In this issue, Bernstein and Okello point to the vulnerability refugees face in refugee settlements in Uganda as one of their main motivations to locate in urban areas.

There is also the important-and regularly overlooked-issue of what refugees, as human beings with histories, desires, and aspirations, want for themselves. The view of most scholars and practitioners who have analyzed encampment policies, as summed up by Richard Black, ${ }^{17}$ is that the majority of benefits of the practice accrue to agencies, states, and other bodies whose objectives are to manage refugees. Limitations to autonomy, freedom of movement, and the institutionalization of refugee livelihoods are widely believed to have detrimental effects on well-being, although naturally camp settings also provide advantages for some refugees or in some circumstances. Specifically, settlements with land available for cultivation by refugees whose former livelihoods depended on agriculture may provide economic opportunity and reassuring stability for a person with a disrupted life. For refugees with particular social, professional, and/or educational backgrounds, who may have no previous experience making a living by cultivating, camps can be quite cruel and demoralizing places. They are marked by complete absence of opportunities for employment, post-primary school education, good quality health care, etc. Refugees who previously worked in the modern sector, including professionals, see no future for themselves or their children in these places. The urban setting holds a natural attraction.

For many such refugees in Africa, cities are places where people can search out services, employment, and safety. Despite the persecution faced by refugees in urban areas at the hands of national and local authorities, there are still greater opportunities for eking out a living than in rural areas. It is also clear from the contributions to this issue that refugees see the presence of international agencies, embassies, and NGOs with an advocacy brief as a means of negotiating other possibilities, such as relocation to a resettlement country. Several of the case studies in this issue $^{18}$ illustrate the preoccupation with obtaining the necessary legal status to enable refugees to travel to Europe, North America, or Australia-even if the possibilities are remote. Currie, for example, describes the strategies of Sudanese refugees in Cairo to acquire resettlement status through marriage and the significance of this status as a source of power in the marriage market. Al-Sharmani shows, furthermore, that refugees with resettlement ambitions move to cities in order to prepare themselves for life in the North-by taking English and computer classes, for example. The employment opportunities for young Somalis in her study also bear out the prospect of earning sums of money unimaginable in a camp setting — such as babysitting for American families in Cairo, who pay refugee domestic workers in foreign currency. These young people aspire to follow the footsteps of others in the Somali diaspora to cities - and citizenship possibilities - in the North. Some of Lammers's subjects of study are artists who run a successful art centre in Kampala (this issue). Without relocating themselves to a city, they would have been unable to develop their skills and knowledge-and a market for their art in Europe. A final example of the opportunities found almost exclusively in cities is the availability of transna- 
tional banking. ${ }^{19}$ Since the incomes of most of the refugees in the areas covered in this issue are supplemented by members of their diasporic communities in the North, living within the urban space facilitates easier, faster, and more effective transnational communications and interactions.

\section{Globalization, Transnationalism, and Urban Refugees}

The marginalized position of urban refugees, particularly in the South, cannot be separated from the mounting pace of globalization and increasing levels of disparity between the North and South. This issue's contributions show how cities in the South serve as "staging grounds" for refugees in transit from one state to another, either through agency-sponsored resettlement programs or via smugglers. In addition to negotiating movement into and between cities, urban refugees also become participants in global flows of information, finance (through remittances), and cultural practices. Despite the interconnectedness promised by the relative ease of communication and travel, refugees living in the African cities described in this issue are severely disadvantaged by their location on the global hierarchy of legal status, which places citizens of Northern states in a considerably superior position in terms of ease of travel and access to resources, among other things. While citizenship is not the only means of calculating the advantages of belonging, ${ }^{20}$ there is a global "market" for privileged nationalities that, when acquired, provide urban refugees with direct or indirect benefits. States in which it is possible to gain full membership are, with few exceptions, those of North America, Europe, and Australia. In contrast, the African and Middle Eastern countries in which the urban refugees in this issue are based do not allow naturalization of non-citizens despite the recent provenance and artificiality of their national borders. Expectations of "local integration" for refugees living in London, Vancouver, Amsterdam, Sydney, and New York are only possible because immigrants are able-at least theoretically - to acquire the legal rights of citizens and the possibility of full citizenship. Refugees residing in Cairo, Johannesburg, Khartoum, and Kampala have no chance of becoming Egyptians, South Africans, Sudanese, or Ugandans, with the national rights and access to resources, though fewer than those of the North, that this implies.

Seen in terms of state policy towards urban refugees in the South, such global inequality provides at least a partial explanation of not only why they are excluded from most services but also why they pose such a perceived threat to Northern states. Kagan's analysis of refugee status determination processes (RSD) notes that Northern states have an interest in keeping the definition of what constitutes refu- gee status narrow to maintain control of immigration, whereas African states have preferred a broader definition (as enshrined in the 1969 OAU Convention relating to the Specific Aspects of the African Refugee Problem, for example), because it serves the purpose of shifting the responsibility for refugees onto international agencies. Kagan also argues that this has the additional effect of depoliticizing the movement of large numbers of people. As both Kagan and Kibreab point out, this state-led strategy leads directly to policies of spatial segregation whereby encamped refugees are "manageable" by international agencies and host governments.

If there are important structural differences between the North and the South which shape global patterns of movement and differential access to citizenship between nations, cities at the same time comprise nodes in transnational refugee networks. In the absence of access to state sponsored resources, including the formal job market, transnational networks make it possible for refugee individuals - and families-to create local livelihoods through remittances, for example, and develop strategies for the long-term improvement of their circumstances. Al-Sharmani's ethnographic research with diasporic Somali families clearly shows the importance of citizenship in a Northern country for the survival—thousands of miles away in Cairo- of urban Somali refugee families. Significantly, the benefits accruing to family members through the support of their relatives in London, Toronto, Amsterdam, and elsewhere do not come without tension as individuals are required to put their own desires - for emigration to the North, for example_-aside for "the good of the family." Given that Somalis and other refugees cannot be granted Egyptian citizenship, with the political, economic, and social integration this implies, Somalis in Cairo instead pursue their goal of citizenship in other places by seeking Somali marriage partners with beneficial passports, studying English, and negotiating with their transnational family members for funding to pay a person smuggler.

Transnational networks benefit newly arrived refugees by connecting them with people who can help them survive in hostile urban environments. Kin, village, neighbourhood, and ethnic links between cities and countries-and connecting cities with refugee camps and home regions, provide refugees with information, food, and shelter. This "bridging social capital" is discussed by D'Addario et al., who point out that a percentage of refugees do not or cannot avail themselves of the housing resources that the Greater Vancouver city district provides refugee newcomers, sheltering instead with contacts from their pre-existing transnational networks. Bernstein and Okello show that cities play an important role regionally as nodes of trans- 
portation and information for fleeing refugees, who often bypass camps on their way to urban areas.

\section{Conclusion}

The issue of urban refugees has received well-deserved attention in recent years as an analytical category as well as a policy concern. The oft-cited re-evaluation by the UNHCR of its 1997 Policy on Urban Refugees is a welcome indication of the growing concern with the discriminatory treatment of refugees in urban areas of the South, both in terms of protection and aid. As Kagan points out in this issue, the UNHCR's mandate is not location-specific. Yet Belvedere's observations of a hostile refugee bureaucracy in South Africa describing a UNHCR beholden to state policies of exclusion reveals a complex double standard whereby refugee status accorded to people living in urban areas does not provide adequate protection. By portraying refugees who move to urban areas as opportunistic, violent, maladjusted, and cultivating a culture of expectation, the UNHCR, like the state interests it represents, legitimates such policies

The recent focus on refugee livelihoods in urban areas directs policy consideration towards the economic and other benefits that urban refugees provide is a welcome refugee-centred approach. ${ }^{21}$ However, policies which define urban refugees in terms of a challenge to existing responses and requiring a different sort of management nevertheless frame refugees as a "problem." If, as the articles in this issue illustrate, even internationally recognized refugees live in insecurity on the margins of urban societies, the difficulty in establishing sustainable livelihoods becomes brutally apparent. D'Addario et al. show that even in a Northern city like Vancouver, refugees rely upon their transnational connections to local networks; refugees in Kampala, in contrast, face the real danger of destitution due to the insecurity of their situation, as shown by Bernstein and Okello, as well as Lammers. Livelihoods are only as sustainable as a person's security and access to resources. Were it not for state-sanctioned controls and restrictions in Africa and other regions of the global South stemming from the definition of refugees as ineligible for citizenship, refugees would be able to establish sustainable livelihoods by developing "bridging social networks" with local hosts 22 and tapping onto their own transnational connections, in turn helping to develop host societies. The concept of urban refugees as a "burden" despite their tiny numbers is a result of inappropriate policies, including UNCHR status determination which reinforces state-sanctioned exclusion. Social capital, which can be developed only in conditions of inclusion, is therefore crucial for the development of sustainable livelihoods.
The contributions to this special issue take a historical and global perspective that critically analyze the processes and constraints shaping the urban environments within which they pursue livelihoods in terms of the political framework of borders, citizenship, and urbanization. Failing to recognize the complex realities which have generated the current context for urban refugees in the South constrains policy makers within the paradigm of the refugeeas-problem. The tendency of governments, noted early on by Kibreab, to deny the existence of refugees as "what the eye refuses to see" 23 has been increasingly challenged by urban refugees themselves, who have demanded that their claim to protection be noticed. Marfleet (this issue) has catalogued a number of protests in cities around the world whereby refugees have demanded an end to their invisibility. The transnational networks of which urban refugees in the South are part also link them to the cities and states of the North, connecting North and South through urban nodes of a global system of flows. As Lammers points out, the repercussions of the global actions and discourses whose centres of power lie historically in the nation-states of the North render all of us the products of violent histories. Urban refugees in the South must be contemplated in this light.

\section{Notes}

1. L. Malkki, "Refugees and Exile: From 'Refugee Studies' to the National Order of Things," Annual Review Anthropology (1995), 495-522; G. Kibreab, "Revisiting the Debate on People, Place, Identity and Displacement," Journal of Refugee Studies 12, no. 4 (1995): 384-410

2. M. Sommers, Fear in Bongoland: Burundi Refugees in Urban Tanzania (New York and Oxford: Berghahn, 2001).

3. South Africa and Egypt have not instituted spatially segregated sites designated for refugees. See Al-Sharmani and Belvedere, this issue.

4. However, it could be argued that, in northern states as well, the rapid expansion of segregated emergency accommodation, the use of detention and deportation of "failed asylum seekers," and enforced periods of legal limbo which prevent refugees from working and studying are similarly designed to prevent integration.

5. G. Kibreab, "Refugeehood, Loss and Social Change: Eritrean Refugees and Returnees," in Refugees and Transformations of Societies: Agency, Policies, Ethics and Politics, ed. P. Essed, G. Frerks, and J. Schrijvers (Oxford: Berghahn Books, 2004), 19-30.

6. B. Buzan, O. Waever, and J. De Wilde, Security: A New Framework for Analysis (London, Boulder: Lynne Rienner, 1998), 23.

7. R. Mandel, The Changing Face of National Security: a Conceptual Analysis (London: Greenwood Press, 1994).

8. Kibreab was conducting fieldwork in Khartoum at this time. 
9. G. Kibreab, "Resistance, Displacement and Identity: The Case of Eritrean Refugees in Sudan," Canadian Journal of African Studies 34, no. 2 (2000): 249-296; A. Karadawi, Refugee Policy in Sudan, 1967-84 (Oxford: Berghahn, 1999); G. Kibreab, "Refugeehood, Loss and Social Change: Eritrean Refugees and Returnees," in Refugees and Transformations of Societies: Agency, Policies, Ethics and Politics, ed. P. Essed, G. Frerks, and J. Schrijvers (Oxford: Berghahn Book 2004), 19-30.

10. Ibid.; G. Kibreab, "The Problem of Refugees in the Sudan: Some Unresolved Issues," in African Refugees: Development Aid and Repatriation, ed. H. Adelman and J. Sorenson (Boulder: Westview Press, 1994), 43-88.

11. M. Sommers, Fear in Bongoland: Burundi Refugees in Urban Tanzania (New York and Oxford: Berghahn, 2001).

12. P. Silverstein, "Immigrant Racialization and the New Savage Slot: Race, Migration, and Immigration in the New Europe," Annual Review of Anthropology 34 (2005), 363-384.

13. For Eritrean and Ethiopian refugees in Sudan see G. Kibreab, "Eritrean and Ethiopian Refugees in Sudan: What the Eye Refuses to See," African Studies Review 39, no. 3 (1996): 131-178; G. Kibreab "Resistance, Displacement and Identity: The Case of Eritrean Refugees in Sudan," Canadian Journal of African Studies 34, no. 2 (2000):249-296; A. Karadawi, Refugee Policy in Sudan, 1967-84 (Oxford: Berghahn, 1999); for Burundian and Rwandese refugees, see B. Rutinwa, "Beyond Durable Solutions: An Appraisal of the New Proposals for Prevention and Solution of the Refugee Crisis in the Great Lakes Region," Journal of Refugee Studies 9 (September 1996): 312-325.; L. Malkki, "National Geographic: The Rooting of Peoples and the Territorialization of National Identity among Scholars and Refugees," Cultural Anthropology 7 (1992): 24-44; for southern Sudanese refugees in Kampala, see E. Lammers, "War, Refuge and Self: Soldiers, Students and Artists in Kampala, Uganda" (PhD thesis, University of Amsterdam, 2006); Lammers and Bernstein and Okello, this issue; for southern Sudanese and Somali refugees in Cairo. see Currie; Al-Sharmani, this issue; for African refugees in South Africa, see Belvedere, this issue.

14. Kagan suggests that the process of determining whether a person has a legitimate refugee claim depends on whether a refugee resides in a rural camp or settlement or an urban location (this issue).

15. It is because of the inability of African states to offer avenues to real integration that they are considered by the international refugee regime to be first countries of asylum. "Resettlement" refers to the admission of refugees from countries where integration is not a legal option to countries in Western Europe, North America, and Australia which provide the possibility of citizenship.
16. See also P. Marfleet, Refugees in a Global Era (London: Polity Press, 2006).

17. R. Black, "Putting Refugees in Camps," Forced Migration Review 2 (1998) 4-7.

18. Belvedere, Al-Sharmani, Currie, Kagan, and Bernstein and Okello (this issue).

19. As Horst has shown, refugees in even the most remote camps now have access to the internet and are connected with international, though unregulated, financial networks. C. Horst, "Transnational Nomads: How Somalis Cope with Refugee Life in the Dadaab Camps of Kenya (PhD thesis, University of Amsterdam, 2003).

20. A. H. Fábos, "Marriage, Sudanese-Style: Transnational Practices of Citizenship and Gender-making for Sudanese Nationals in Egypt, Northeast African Studies (New Series) 8 (2001): 277-301.

21. K. Jacobsen, "Editorial Introduction: Refugees and Asylum Seekers in Urban Areas: A Livelihoods Perspective," Journal of Refugee Studies 19, no. 3 (2006): 273-286.

22. M. Korac, "The Role of Bridging Social Networks in Refugee Settlement: A Case of Italy and the Netherlands," in Homeland Wanted: Interdisciplinary Perspective on Refugee Resettlement in the West, ed. Peter Waxman and Val Colic-Peisker (New York: Nova Science Publishers, 2005).

23. In Kenya, for example, the government continues to deny the presence of refugees in Nairobi; see Human Rights Watch, Hidden in Plain View (New York: Human Rights Watch, 2002), http://www.hrw.org/reports/2002/kenyugan. In Cairo, the Egyptian government has continually sidestepped the issue of refugees.

Anita Fábos is programme leader for the postgraduate Refugee Studies Programme at the University of East London. Formerly Director of Forced Migration and Refugee Studies at the American University in Cairo, she has conducted extensive research with urban refugees in Cairo.

Professor Gaim Kibreab is director of the post-graduate program in refugee studies at London Southbank University. Dr. Kibreab's work has focused largely on Eritrea and the Sudan, including a recent book on state intervention and the environment in Sudan.

We are grateful to Nadine Fernandez and Maja Korac for reading earlier versions of this essay. 